\title{
Captive breeding of the endangered freshwater pearl mussel Margaritifera margaritifera
}

\author{
G. R. Thomas' ${ }^{1}$ J. Taylor ${ }^{2}$, C. Garcia de Leaniz ${ }^{1, *}$ \\ ${ }^{1}$ Swansea University, Department of Pure \& Applied Ecology, Singleton Park SA2 8PP, Swansea, UK \\ ${ }^{2}$ Environment Agency Wales, Cynrig Fish Culture Unit, Brecon, Powys LD3 7AX, UK
}

\begin{abstract}
Freshwater pearl mussels (Unionidae: Bivalvia) rank among the most endangered aquatic invertebrates, and this has recently prompted a number of initiatives designed to propagate the species through captive breeding. Yet there are few guidelines to aid in freshwater mussel culture for conservation, and few or no results on the fate of released juveniles. We reviewed various ex situ strategies for freshwater mussel conservation with emphasis on the freshwater pearl mussel Margaritifera margaritifera (L.), one of the most critically endangered unionids. Captive breeding could help safeguard critically endangered populations, but current rearing methods need to be optimised. Areas in particular need of research include the collection and storage of viable glochidia, the development of efficient rearing systems, and the formulation of algal diets. Likewise, the degree of host specificity warrants further investigation, as this will largely dictate the success of reintroduction programmes. Finally, we note that more information is needed on the degree of genetic structuring and post-release survival before translocation programmes can be recommended. As with other conservation projects, captive breeding of the freshwater pearl mussel cannot compensate for loss of critical habitats and is likely to be most efficient in combination with in situ conservation, not in isolation.
\end{abstract}

KEY WORDS: Freshwater pearl mussel - Margaritifera margaritifera - Captive breeding . Host specificity · Juvenile culture

\section{INTRODUCTION}

Freshwater pearl mussels (Unionacea) are among the most endangered aquatic organisms in the world (IUCN 1996, Strayer et al. 2004). With a maximum life span in excess of $100 \mathrm{yr}$, some pearl mussels also rank among the slowest-growing and longest-living known invertebrates (Ziuganov et al. 2000, Anthony et al. 2001), which makes their conservation particularly problematic (Cosgrove \& Hastie 2001, Hastie et al. 2003).

The accelerated decline of many freshwater mussels has recently prompted a flurry of initiatives designed to propagate and restore the species in Europe (Buddensiek 1995, Beasley \& Roberts 1999, Hastie \& Young 2003a, Preston et al. 2007) and elsewhere (Strayer et al. 2004, Barnhart 2006). In the UK, unprecedented steps have recently been taken to safeguard entire Margari- tifera margaritifera (L.) populations by collecting adults from the wild and bringing them into captivity in the hope of establishing living gene banks and aiding the recovery of self-sustaining populations (Taylor 2007). Yet, there is a paucity of data on critical life stages, the relative merits of different conservation strategies, and the fate of cultured juveniles.

Given that resources allocated to mussel conservation are always likely to be limited, it is essential to weigh up and prioritise the different options available to freshwater managers and wildlife officials (Araujo \& Ramos 2001). There are relatively few published studies on conservation of freshwater mussels compared to other freshwater mussel topics (Fig. 1), despite the fact that these species are increasingly imperiled. Whilst the in situ requirements of different freshwater mussel species have already been discussed by others (Neves 


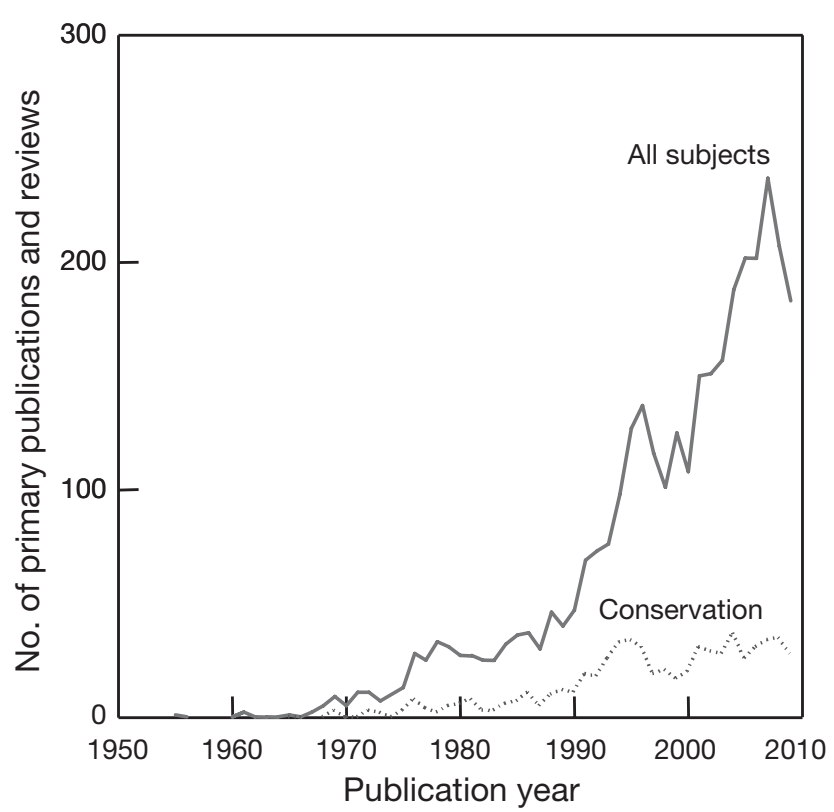

Fig. 1. Trends in the total number of primary publications and reviews on freshwater mussels (All subjects) and those that deal specifically with conservation issues (conservation). Data are from the ISI Web of Science (Conservation) (www. isiknowledge.com). While research effort on freshwater mussels has grown exponentially over the last 2 decades, relatively little of it has been directed towards addressing the conservation needs of mussels despite the fact that they are becoming increasingly imperiled

\& Widlak 1987, Layzer \& Madison 1995, Valovirta 1998, Hastie et al. 2000, Brainwood et al. 2008, Geist 2010), few guidelines exist for ex situ conservation. Here, we critically review various strategies for ex situ conservation of the freshwater pearl mussel, examine the main gaps in knowledge, and indicate those areas in most need of research. Although we have largely focused our attention on the freshwater pearl mussel, we have also drawn information from other freshwater mussels, where appropriate. Our objectives were 2fold: (1) to illustrate the range of options available for the artificial propagation of freshwater mussels, and (2) to weigh the main advantages and limitations of different captive breeding strategies for conservation.

\section{STRATEGIES FOR EX SITU CONSERVATION}

The conservation of Margaritifera margaritifera faces several challenges, not least being the low rates of recruitment in natural populations. This is offset by a long reproductive lifespan and high fecundity, although freshwater pearl mussels do not reach sexual maturity until an age of 10 to 20 yr (Bauer 1987a, Skinner et al. 2003). Ex situ conservation of freshwater pearl mussels involves some or all of the following steps (Fig. 2): (1) fertilisation of females in captivity, (2) infection and encystment of glochidia in suitable fish hosts, (3) stocking of infected fish into existing or historical mussel rivers, (4) harvesting and rearing of excysted larvae, and (5) release of captive-reared juvenile mussels. Historically, ex situ conservation projects have, on the whole, been uncoordinated and poorly planned, with results difficult to quantify due to the slow turnover of this species (Hastie \& Young 2003a).

\section{Fertilisation of females in captivity}

Mussel fertilisation rates are known to be influenced by the spatial distribution of broodstock (Downing et al. 1993), and the aim of aggregating adult mussels in captivity is to achieve higher fertilisation rates and greater production of glochidia. In common with other freshwater bivalves, sexes in the freshwater pearl mussel are separate (dioecious) and reproduction takes place after 10 to 20 yr, typically in February or March (Young \& Williams 1984a,b, Skinner et al. 2003). Males release sperm into the water; the sperm is carried downstream and inhaled by females to fertilise their eggs, which are kept in modified marsupia in the gills (Smith 1979, Skinner et al. 2003). Fertilisation often occurs synchronously within a population, and appears also to be linked to water temperature (Ross 1992, Buddensiek 1995, Hastie \& Young 2003b), as in other species of freshwater mussel (Watters \& O'Dee 1999). At low densities, females can turn hermaphroditic, but whether this results in self-fertilisation is not clear (Bauer 1987b, Hanstén et al. 1997).

It is as yet unclear how many adults are required to achieve a reproductively viable population in captivity. In Wales, the Freshwater Pearl Mussel Recovery Group advocated in 2005 the collection from the wild of all adult mussels in the most critically endangered populations (those consisting of fewer than 100 mussels), and the rearing in captivity of at least 50 adult mussels from each of the other populations (Taylor 2007).

Adult mussels have been kept in flow-through systems fed with river water or in re-circulating systems. In flow-through systems, mussel broodstock can be maintained in salmonid hatchery troughs supplied with filtered river water $(30 \mu \mathrm{m})$ to reduce sediment loads, and covered with sand and gravel (Hastie \& Young 2003a, Preston et al. 2007). Very little is known about the diet requirements of adult Margaritifera margaritifera, although information from other freshwater bivalves suggests that they probably feed on freshwater algae within the 15 to $40 \mu \mathrm{m}$ range (Winkel $\&$ Davids 1982). In the wild, Mandal et al. (2007) found varying proportions of blue-green algae, green algae and diatoms in the gut of the freshwater mussel Lamel- 


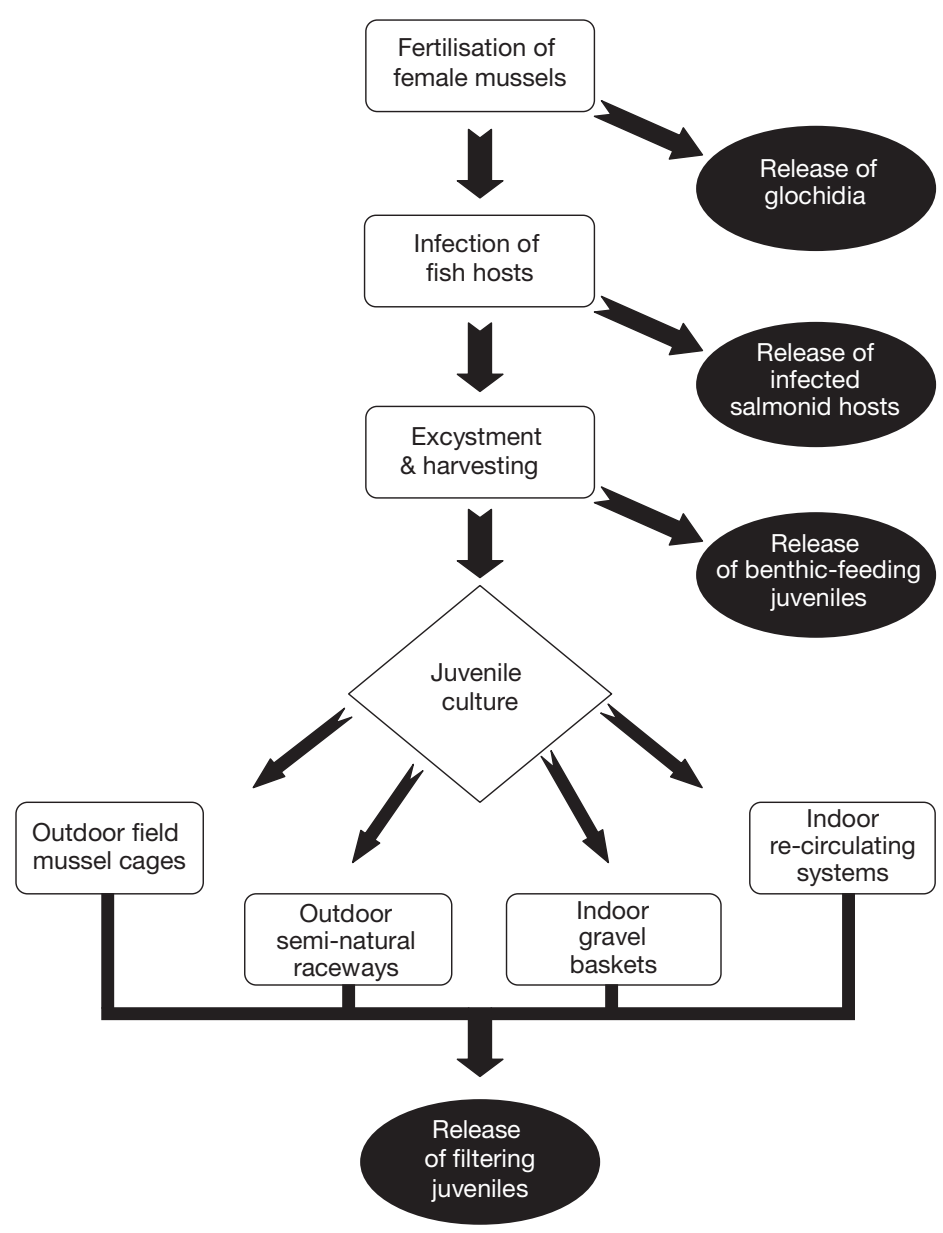

Fig. 2. Ex situ conservation strategies for the propagation of the freshwater pearl mussel Margaritifera margaritifera. See 'Strategies for ex situ conservation' for details on each strategy

lidens marginalis. Mussels kept in recirculating systems need to be fed with a suitable algal diet, but it is unclear whether supplemental feeding is needed in flow-through systems, or what effects, if any, different diet may have on reproduction and gamete quality. Recent research on stable isotope composition of mussel shells (Geist et al. 2005) may assist in the formulation of suitable diets for captive mussels.

\section{Infection of fish hosts and host specificity}

Although glochidia of most unionid mussels can readily attach to the tissue and gill filaments of various fish species (Strayer et al. 2004), metamorphosis and full larval development is normally only possible on a few host species (Dodd et al. 2006). In the case of Margaritifera margaritifera, each female can release between 1 million and 4 million glochidia, which drift downstream and die within 24 to $48 \mathrm{~h}$ if they cannot attach to a suitable fish host (Hastie \& Young 2003b), although in some cases they can remain infective for up to 6 d (Ziuganov et al. 1994, Skinner et al. 2003). Margaritiferids appear to be highly host-specific, being closely linked to non-migratory brown trout Salmo trutta and migratory fishes-salmonids in the case of M. margaritifera, and acipenserids in the case of M. auricularia (Altaba 1990, Ziuganov et al. 1994, Bauer 2000). The Atlantic salmon Salmo salar is thought to be the primary fish host for M. margaritifera across its range (Ziuganov 2005), although brook trout Salvelinus fontinalis in eastern North America and brown trout in Europe can also act as suitable hosts (Young \& Williams 1984b, Bauer 1987a, 2000, Cunjak \& McGladdery 1991, Hastie \& Young 2001, 2003b, Morales et al. 2004). Artic charr Salvelinus alpinus may also act as a viable fish host in northern Europe (Bauer 1987a), but this has not yet been confirmed (Hastie \& Young 2001). Walker (2007) noted that, although rare, S. alpinus coexist in rivers with $M$. margaritifera in Scotland, providing the opportunity for glochidia to encyst on this species.

What seems clear is that Margaritifera margaritifera cannot metamorphose in the gills of Pacific salmonids (Young \& Williams 1984a, Bauer 2000, Skinner et al. 2003, Ziuganov 2005). Earlier accounts on the susceptibility of Pacific salmonids to $M$. margaritifera in western North America (Meyers \& Millemann 1977) are now believed to refer to the closely related species M. falcata (Stone et al. 2004), and may explain the contradictory results. Table 1 summarises the known hosts of $M$. margaritifera across its range. The extent to which freshwater pearl mussels show intraspecific variation in host specificity is not known and warrants further study, as this may dictate the success of reintroduction programmes.

\section{Encystment of glochidia}

Perhaps the simplest way to achieve host encystment of glochidia is by making gravid mussels cohabit with juvenile salmonids in hatchery troughs (Treasurer et al. 2006). Typically 0+ salmonid fry are used (either Atlantic salmon or brown trout) to maximise encystment, as older salmonid parr may show acquired immunity from previous exposures (Treasurer et al. 2006). Rearing salmonids and mussels together appears to result in high encystment rates (Treasurer et al. 2006), and it is possible that the release of glochidia in Margaritifera margaritifera is facilitated by the close 
Table 1. Geographic variation in the salmonid hosts of the freshwater pearl mussel Margaritifera margaritifera. (?): Host species uncertain

\begin{tabular}{|c|c|c|}
\hline Country & Salmonid host & Source \\
\hline Austria & Salmo trutta & Lahnsteiner \& Jagsch (2005) \\
\hline Belgium & S. trutta & Araujo \& Ramos (2001) \\
\hline Czech Republic & S. trutta & Hruska (1999) \\
\hline Estonia & Salmo salar, S. trutta & Geist et al. (2006) \\
\hline Finland & S. salar, S. trutta & Araujo \& Ramos (2001) \\
\hline France & S. salar, S. trutta & Araujo \& Ramos (2001) \\
\hline Germany & S. trutta, Salvelinus alpinus? & Bauer (1987a), Bauer \& Vogel (1987), Buddensiek (1995) \\
\hline Great Britain & S. salar, S. trutta, S. alpinus? & $\begin{array}{l}\text { Young \& Williams (1983), Bauer (1987a), Hastie \& Young } \\
(2001,2003 a)\end{array}$ \\
\hline Ireland & S. salar, S. trutta & Beasley \& Roberts (1999) Preston et al. (2007) \\
\hline Latvia & S. trutta & Rudzite (2004) \\
\hline Luxembourg & S. trutta & Araujo \& Ramos (2001) \\
\hline Norway & S. salar, S. trutta & Wächtler et al. (2000) \\
\hline Portugal & S. salar, S. trutta & Reis (2003) \\
\hline Russia & S. salar, S. trutta & Ziuganov et al. (1994) \\
\hline Spain & S. salar, S. trutta & Alvarez-Claudio et al. (2000), Morales et al. (2004) \\
\hline Sweden & S. salar, S. trutta & Erikson et al. (1998) \\
\hline USA (northeast) & S. salar, Salvelinus fontinalis, S. trutta? & Cunjak \& McGladdery (1991) \\
\hline
\end{tabular}

proximity of suitable fish hosts, as shown in other freshwater mussels (Haag \& Warren 2000). Research on the role of fish hosts in triggering $M$. margaritifera spatting would seem warranted in order to optimise captive breeding programmes.

As an alternative to the cohabitation method, the outflow of tanks housing gravid mussels can be diverted into fish tanks housing hatchery-reared juvenile salmonids (Hastie \& Young 2003a, Preston et al. 2007). Hastie \& Young $(2001,2003 a)$ showed that large numbers of Atlantic salmon and brown trout could be infected in this way, with glochidia loads ranging between 10 and 800 glochidia per fish. More recently, Preston et al. (2007) used the same approach to infect large numbers of juvenile brown trout, with low $(\sim 1 \%)$ host mortalities.

In captivity, released glochidia which do not find their way into fish hosts can often be observed as a white, dense cloud in or around the adult female. This can be collected, diluted if necessary and either poured directly into hatchery tanks, or be given as a bath to batches of fish in small volumes of water to achieve infection. Spatting can also be induced in captivity, when it does not occur naturally. To induce glochidia release, gravid females are first placed in chilled de-chlorinated tap water. The release of glochidia is usually observed within $1 \mathrm{~h}$ as water rises to room temperature (Meyers \& Millemann 1977). Induction of spatting is believed to be caused by thermal shock and respiratory stress, resulting in the forced release of glochidia from the modified gill marsupia to reduce oxygen demand; more oxygen becomes available to the female after expelling the brooding glochidia (Hastie \& Young 2003b). Glo- chidia are then examined for viability, with cilia movement and 'winking' of valves as viability criteria; various salt concentrations can also be used to elicit an open/close response to determine glochidia viability (Meyers \& Millemann 1977). Only glochidia spawned on the same day are normally used. The use of induced glochidia allows better control over exposure concentrations, but it is not known to what extent this method compromises glochidia viability compared to the viability of those obtained from naturally spawned mussels. Indeed, spat induced by thermal shock have sometimes been found to consist of immature, non-viable glochidia.

\section{Stocking of infected fish hosts}

The release of artificially infected hosts into rivers has a long history (Buddensiek 1995, Valovirta 1998, Hruska 2001, Preston et al. 2007), although results have been difficult to quantify. In Germany, and more recently also in the British Isles, there have been large releases of infected salmonid hosts, but evidence for recruitment of second-generation juvenile mussels is lacking (Hastie \& Young 2003a). In theory, the release of artificially infected hosts makes conservation sense, as the maturing glochidia would fall from the host and populate the rivers in a 'natural' way, and would also reduce the costs and time associated with an extended period of juvenile mussel rearing in captivity. Moreover, artificial infection typically results in glochidia loads many times higher than those commonly found in the wild (Karna \& Millemann 1978, Hruska 2001), 
which may aid in the propagation of freshwater mussels. However, mortality of hatchery-reared salmonids is usually very high immediately following stocking (Aprahamian et al. 2003), and most excysted glochidia do not seem to find a suitable substrate in which to continue their development (Buddensiek 1995, Hastie \& Young 2003a).

\section{Harvesting and rearing of excysted (post-parasitic) juvenile mussels}

An alternative to the release of infected fish hosts carrying glochidia is the captive-rearing of juvenile mussels through the post-parasitic stage. This is expected to offer greater control over the survival and growth of mussels (Treasurer et al. 2006, Preston et al. 2007), but it represents a long-term programme that requires a committed facility and staff, as several years will pass between infecting the fish hosts and the production of juvenile mussels for restoration.

It takes around 10 mo for glochidia to develop on suitable salmonid fish hosts, but $95 \%$ of glochidia die before reaching this stage (Hastie \& Young 2003a). After completing development, glochidia excyst from host tissue, fall away and must be collected, typically in plankton nets placed directly over outflow pipes (Buddensiek 1995). Juveniles can then be transferred to outgrow tanks and maintained for the next few years, until they are large enough to survive in the wild or taken into the next rearing phase. Some knowledge on the timing of excystment is advantageous to optimise the collection of mussel seed in the following spring (Hastie \& Young 2003a). Hruska (1992) first proposed the concept of 'degree days' required to reach excystment, and concluded that a period of $15^{\circ} \mathrm{C}$ water temperature was required for the last few weeks. At captive breeding facilities in Wales, juveniles have excysted following an average of 2381 degree days during the period 2005 to 2008 (range $=2229-2619$ degree days). By keeping a record of degree days, $150 \mu \mathrm{m}$ mesh plankton nets can be placed over outflow pipes in anticipation of juvenile excystment, and the feeding regimes of host fish reduced to make it easier to harvest the post-parasitic juveniles. Post-parasitic juvenile mussels begin to pedal-feed on algae and organic matter as soon as they fall from the fish host, and will therefore require suitable substrate for their initial development (Geist \& Auerswald 2007). The transition from benthic to filter feeding represents a critical period for survival in captive breeding programmes (Hastie \& Young 2003a), as the early juvenile stages appear to be very vulnerable to disturbance and have narrow substrate requirements (Young \& Williams 1983). Several factors are critical for their survival and growth, including substrate type, silt content, water quality and an adequate supply of nutrients (Skinner et al. 2003, Geist et al. 2006). Barnhart (2006) found that occasional handling improved juvenile survival in North American freshwater mussels, possibly due to the removal of silt and debris. Predation and competition by microfauna may also play an important role in early juvenile mortality (Zimmerman et al. 2003). Several methods have been employed in the culture of juvenile freshwater pearl mussels, including the use of outdoor mussel cages, semi-natural stream channels, salmonid hatching baskets and recirculation systems (Fig. 2).

\section{Mussel cages}

The use of mussel cages to rear excysted juvenile Margaritifera margaritifera in the wild was pioneered by Buddensiek (1995). Mortality amongst post-parasitic juveniles was found to be around $70 \%$ during the first months (June to December), but decreased after the first winter. Only animals larger than $900 \mu \mathrm{m}$ had a $50 \%$ chance of surviving to their second growing period, and all juveniles less than $700 \mu \mathrm{m}$ in size died during the June to December period. Therefore, initial size appeared to be a critical factor for survival of juvenile mussels. In a similar study in Scotland, Hastie \& Young (2003a) reported a $3 \%$ survival rate after 12 mo of cage rearing in the wild. In comparison, juvenile $M$. margaritifera kept in similar mussel cages at a hatchery attained a $7 \%$ survival rate after 10 mo. Thus, while mussel cages may offer some advantages for the culture of juvenile mussels under more natural conditions, current methods would need to be optimised and scaled up for conservation purposes. In this sense, an upwelling 'mussel-silo' cage system has recently been developed in North America to rear juvenile mussels in flowing waters with reduced risk of siltation (Barnhart 2006).

\section{Semi-natural stream channels}

Preston et al. (2007) recently assessed the merits of using hatchery raceways covered with gravel to serve as semi-natural stream channels for the rearing of encysted salmonids. Excysted mussels were allowed to fall in the substrate and complete their development, and analysis of gravel core samples approximately $1 \mathrm{yr}$ after the introduction of encysted hosts showed relatively high densities of juvenile mussels, up to 13200 mussels in 1 cohort. This study was the first in the UK to culture and maintain large numbers of juvenile pearl mussels for restoration purposes, although similar methods have been used in the United States with 
other freshwater mussels (Williams et al. 1993, Beaty \& Neves 2004). The advantages of this method include that it capitalises on high encystment loads of artificially infected hosts, and allows glochidia to excyst under more controlled substrate and flow conditions. However, it is as yet unclear whether this method can be scaled up for long-term propagation, how long mussels should be kept in stream channels, or what precautions are needed to harvest delicate juveniles from the natural substrate.

\section{Salmonid hatching baskets}

The use of hatching baskets represents the most widespread method of culturing freshwater pearl mussels during the early stages (Hastie \& Young 2003a, Skinner et al. 2003). Excysted juvenile mussels are collected in outflow mesh screens and transferred to indoor salmonid hatchery troughs fitted with hatching baskets covered with a 1 to $2 \mathrm{~mm}$ layer of fine gravel (150 to $500 \mu \mathrm{m}$ ). Filtered river water upwells through each gravel basket, helping to reduce silt loads, while algae and organic matter enrich the gravel and provide nutrition for the juveniles. Post-parasitic mussels can be reared in this way for 12 to $18 \mathrm{mo}$, until they are large enough to be transferred to larger facilities or released into the wild (Hastie \& Young 2003a). Survival of juvenile mussels reared by this method appeared to have been high during the first few months post-excystment (Taylor 2007), but this was followed by high mortalities during the second year. As with other rearing systems, little is known about causes of juvenile mussel mortality in captivity, although predation by flatworms, mechanical damage and silting up are thought to be important at the post-parasitic stage (Zimmerman et al. 2003, Barnhart 2006).

\section{Recirculation systems}

Recirculation systems offer greater control over environmental variables than typical flow-through facilities, and these have been tried successfully for culturing various species of freshwater mussels in North America (Jones \& Neves 2002, Jones et al. 2004, 2005, Barnhart 2006), but not yet in Margaritifera margaritifera. Mussel recirculating systems typically consist of nested chambers with a downwelling flow at a rate of ca. $400 \mathrm{l} \mathrm{h}^{-1}$ (Barnhart 2006). Substrate is required in recirculating systems for growth and survival, although this can perhaps make juvenile mussels more vulnerable to flatworm predation (Zimmerman et al. 2003). Supplemental feeding of unicellular green algae has also been found necessary (Barnhart 2006), but lit- tle is known about optimal algal diets. For example, survival in captivity of juveniles of the dromedary pearly mussel Dromus dromas was 30\% after 2 wk when fed the green alga Nannochloropsis oculata (Jones et al. 2004). Growth and survival of juvenile freshwater mussels appears to be higher in flowthrough than in recirculating systems (Jones \& Neves 2002), possibly due to diet imbalance. Early survival and growth are also higher when juvenile bivalves are reared on natural sediments rather than on commercial shellfish diets (Naimo et al. 2000), emphasising that for many species the formulation of algal diets constitutes one of the greatest challenges for captive rearing.

\section{Stocking of juvenile mussels}

Some attempts have been made to release glochidia directly into upstream tributaries to infect wild hosts, although there are no results available to ascertain the success of this strategy (Geist \& Kuehn 2005). On the other hand, releases of cultured post-parasitic freshwater pearl mussels have not yet occurred, as these have not been cultured in sufficient numbers. The aim of the captive breeding of unionid mussels is to release individuals back into rivers at some point in the future. The success of the programme will therefore ultimately depend on the ability of captive-bred individuals to survive and reproduce in the natural environment, not on the success of the rearing programme itself. However, it is unknown whether captive populations will adapt to the natural environment, and how juvenile mussels will fare compared to wild populations; this is an area where research is urgently needed (Hoftyzer et al. 2008).

\section{CONCLUSIONS}

As with other unionid mussels, the conservation of Margaritifera margaritifera is problematic and exacerbated by the continuation of many practices that actively contribute to their decline (Strayer 2008). The problems of silt pollution, unsympathetic riparian management, habitat fragmentation and declining host populations need to be addressed whilst there are still sufficient numbers of reproductively viable adult mussels. In common with other freshwater mussels (Berg et al. 2007, Elderkin et al. 2007, Zanatta \& Murphy 2007), M. margaritifera shows a significant degree of population structuring (Machordom et al. 2003), even at small spatial scales (Geist \& Kuehn 2005, Bouza et al. 2007). Areas colonised by $M$. margaritifera since the last glacial maxima display high genetic diversity (Geist \& Kuehn 2008, Geist et al. 2009), and this may be indica- 
tive of locally adapted populations, as seen in their salmonid hosts (Garcia de Leaniz et al. 2007), and should be taken into account when developing ex situ conservation programmes for the species (Geist \& Kuehn 2005). For example, translocations of mussels between watersheds or introduction of artificially reared individuals may result in gene introgression and the breakdown of local adaptations, further compromising the conservation of depleted populations. Given what has been learned over the last few decades about the genetic risks of fish stocking (reviewed by Cross et al. 2007), the artificial propagation of freshwater mussels should take into account the genetic variation, effective population size and number and extent of neighbouring mussel conservation units. It can be argued that until the situation in rivers improves, the conservation of this species will depend on captive breeding. There may simply be too few individuals to maintain self-sustaining populations, particularly in the face of sudden pollution events, massive floods or other catastrophes. However, it can also be argued that unless the underlying threats facing the species are also addressed, captive breeding alone is unlikely to save endangered freshwater mussels from extinction. Indeed, relying on captive breeding alone is dangerous and is what Meffe (1992) termed 'technoarrogance' and 'half-way technologies', i.e. when resources are simply diverted from habitat protection to artificial propagation, and technology is used for treating the symptoms rather than the causes of decline. Captive breeding cannot be a substitute for habitat restoration (Christian \& Harris 2008), and singlespecies approaches are unlikely to work with pearl mussels, as these can conflict with the conservation of other species (see Geist \& Kuehn 2008). Instead, success is most likely to come from multi-faceted projects which take a holistic, integral approach to conservation and rely on 4 underlying principles: (1) legal protection and policing, (2) public awareness, (3) habitat restoration and (4) artificial breeding.

Acknowledgements. We thank S. Consuegra and 3 anonymous referees for making useful comments on the manuscript.

\section{LITERATURE CITED}

Altaba CR (1990) The last known population of the freshwater mussel Margaritifera auricularia (Bivalvia, Unionoida): a conservation priority. Biol Conserv 52:271-286

> Alvarez-Claudio CA, Garcia-Roves P, Ocharan R, Cabal JA, Ocharan FJ, Alvarez MAA (2000) A new record of the freshwater pearl mussel Margaritifera margaritifera L. (Bivalvia: Unionoida) from the River Narcea (Asturias, north-western Spain). Aquatic Conserv Mar Freshw Ecosyst 10:93-102
Anthony JL, Kesler DJ, Downing WL, Downing JA (2001) Length-specific growth rates in freshwater mussels (Bivalvia: Unionidae): extreme longevity or generalized growth cessation? Freshw Biol 46:1349-1359

Aprahamian MW, Smith KM, McGinnity P, McKelvey S, Taylor J (2003) Restocking of salmonids - opportunities and limitations. Fish Res 1431:1-17

Araujo R, Ramos MA (2001) Action plan for Margaritifera margaritifera. Convention on the Conservation of European Wildlife and Natural Habitats (Bern Convention). Nature and environment, No. 117. Council of Europe Publishing, Strasbourg, p 29-66

Barnhart MC (2006) Buckets of muckets: a compact system for rearing juvenile freshwater mussels. Aquaculture 254: $227-233$

Bauer G (1987a) The parasitic stage of the freshwater pearl mussel (Margaritifera margaritifera L.). II. Susceptibility of brown trout. Arch Hydrobiol 76:403-412

Bauer G (1987b) Reproductive strategy of the freshwater pearl mussel Margaritifera margaritifera. J Anim Ecol 56: $691-704$

Bauer G (2000). Life-history variation on different taxonomic levels of naiads. In: Bauer G, Wächtler K (eds) Ecology and evolution of the freshwater mussels Unionoida. Springer, New York, NY, p 83-92

Bauer G, Vogel C (1987) The parasitic stage of the freshwater pearl mussel (Margaritifera margaritifera L.). I. Host response to glochidiosis. Arch Hydrobiol 76:393-402

Beasley CR, Roberts D (1999) Towards a strategy for the conservation of the freshwater pearl mussel Margaritifera margaritifera in County Donegal, Ireland. Biol Conserv 89:275-284

Beaty BB, Neves RJ (2004) Use of natural water flow-through culture system for rearing juvenile freshwater mussels (Bivalvia: Unionidae) and evaluation of the effects of substrate size, temperature, and stocking density. Am Malacol Bull 19:15-23

Berg DJ, Christian AD, Guttman SI (2007) Population genetic structure of three freshwater mussel (Unionidae) species within a small stream system: significant variation at local spatial scales. Freshw Biol 52:1427-1439

> Bouza C, Castro J, Martínez P, Amaro R and others (2007) Threatened freshwater pearl mussel Margaritifera margaritifera L. in NW Spain: low and very structured genetic variation in southern peripheral populations assessed using microsatellite markers. Conserv Genet 8:937-948

Brainwood M, Burgin S, Byrne M (2008) The role of geomorphology in substratum patch selection by freshwater mussels in the Hawkesbury-Nepean River (New South Wales) Australia. Aquatic Conserv Mar Freshw Ecosyst 18: 1285-1301

Buddensiek V (1995) The culture of juvenile freshwater pearl mussels Margaritifera margaritifera L. in cages: a contribution to conservation programmes and the knowledge of habitat requirements. Biol Conserv 74:33-40

> Christian AD, Harris JL (2008) An introduction to directions in freshwater mollusk conservation: molecules to ecosystems. J N Am Benthol Soc 27:345-348

Cosgrove PJ, Hastie LC (2001) Conservation of threatened freshwater pearl mussel populations: river management, mussel translocation and conflict resolution. Biol Conserv 99:183-190

Cross TF, McGinnity P, Coughlan J, Dillane E and others (2007) Stocking and ranching. In: Verspoor E, Nielsen J, Stradmeyer L (eds) The Atlantic salmon: genetics, conservation and management. Blackwell, London, p 325-356

> Cunjak RA, McGladdery SE (1991) The parasite-host relationship of glochidia (Mollusca: Margaritiferidae) on the 
gills of young-of-the-year Atlantic salmon (Salmo salar). Can J Zool 69:353-358

Dodd BJ, Barnhart MC, Rogers-Lowery CL, Fobian TB, Dimock RV Jr (2006) Persistence of host response against glochidia larvae in Micropterus salmoides. Fish Shellfish Immunol 21:473-484

$>$ Downing JA, Rochon Y, Perusse M, Harvey H (1993) Spatial aggregation, body size and reproductive success in the freshwater mussel Elliptio complanata. J N Am Benthol Soc 12:148-156

Elderkin CL, Christian AD, Vaughn CC, Metcalfe-Smith JL, Berg DJ (2007) Population genetics of the freshwater mussel, Amblema plicata (Say 1817) (Bivalvia: Unionidae): evidence of high dispersal and post-glacial colonization. Conserv Genet 8:355-372

Erikson MEG, Henrikson L, Söderberg H (1998) The freshwater pearl mussel Margaritifera margaritifera in Sweden. Naturvardsverket Forlag, Stockholm

Garcia de Leaniz C, Fleming IA, Einum S, Verspoor E and others (2007) A critical review of adaptive genetic variation in Atlantic salmon: implications for conservation. Biol Rev Camb Philos Soc 82:173-211

Geist J (2010) Strategies for the conservation of endangered freshwater pearl mussels (Margaritifera margaritifera L.): a synthesis of conservation genetics and ecology. Hydrobiologia 644(1):69-88

Geist J, Auerswald K (2007) Physicochemical stream bed characteristics and recruitment of the freshwater pearl mussel (Margaritifera margaritifera). Freshw Biol 52: $2299-2316$

Geist J, Kuehn R (2005) Genetic diversity and differentiation of central European freshwater pearl mussel (Margaritifera margaritifera L.) populations: implications for conservation and management. Mol Ecol 14:425-439

Geist J, Kuehn R (2008) Host-parasite interactions in oligotrophic stream ecosystems: the roles of life-history strategy and ecological niche. Mol Ecol 17:997-1008

Geist J, Auerswald K, Boom A (2005) Stable carbon isotopes in freshwater mussel shells: environmental record or marker for metabolic activity? Geochim Cosmochim Acta 69:3545-3554

Geist J, Porkka M, Kuehn R (2006) The status of host fish populations and fish species richness in European freshwater pearl mussel (Margaritifera margaritifera) streams. Aquat Conserv Mar Freshw Ecosyst 16:251-266

Geist J, Soderberg H, Karlberg A, Kuehn R (2009) Drainageindependent genetic structure and high genetic diversity of endangered freshwater pearl mussels (Margaritifera margaritifera) in northern Europe. Conserv Genet doi:10.1007/s10592-009-9963-4

Haag WR, Warren ML (2000) Effects of light and presence of fish on lure display and larval release behaviours in two species of freshwater mussels. Anim Behav 60: 879-886

Hanstén C, Pekkarinen M, Valovirta I (1997) Effect of transplantation on the gonad development of the freshwater pearl mussel, Margaritifera margaritifera (L.). Boreal Environ Res 2:247-256

Hastie LC, Young MR (2001) Freshwater pearl mussel (Margaritifera margaritifera) glochidiosis in wild and farmed salmonid stocks in Scotland. Hydrobiologia 445:109-119

Hastie LC, Young MR (2003a) Conservation of the freshwater pearl mussel I: captive breeding techniques. Conserving Natura 2000 Rivers Ecology Series No. 2, English Nature, Peterborough

> Hastie LC, Young MR (2003b) Timing of spawning and glochidial release in Scottish freshwater pearl mussel
(Margaritifera margaritifera) populations. Freshw Biol 48: $2107-2117$

Hastie LC, Boon PJ, Young MR (2000) Physical microhabitat requirements of freshwater pearl mussels, Margaritifera margaritifera (L.). Hydrobiologia 429:59-71

> Hastie LC, Cosgrove PJ, Ellis N, Gaywood MJ (2003) The threat of climate change to freshwater pearl mussel populations. Ambio 32:40-46

Hoftyzer E, Ackerman JD, Morris TJ, Mackie GL (2008) Genetic and environmental implications of reintroducing laboratory-raised unionid mussels to the wild. Can J Fish Aquat Sci 65:1217-1229

Hruska J (1992) The freshwater pearl mussel in South Bohemia: evaluation of the effect of temperature on reproduction, growth and age structure of the population. Arch Hydrobiol 126:181-191

Hruska J (1999) Nahrungsansprüche der Flussperlmuschel und deren halbnatürliche Aufzucht in der Tschechischen Republik. Heldia 4:69-79

Hruska J (2001) Experience of semi-natural breeding programme of freshwater pearl mussels in the Czech Republic. In: The freshwater pearl mussel in Europe: population status and conservation strategies. Report of the International Congress on Pearl Mussel Conservation 2000, Freiburg, p 69-75

IUCN (International Union for Conservation of Nature) (1996) Mollusc specialist group Margaritifera margaritifera. In: IUCN Red List of Threatened Species, Version 2010.1. www.iucnredlist.org

> Jones JW, Neves RJ (2002) Life history and propagation of the endangered fanshell pearly mussel, Cyprogenia stegaria Rafinesque (Bivalvia:Unionidae). J N Am Benthol Soc 21: 76-88

> Jones JW, Neves RJ, Ahlstedt SA, Mair RA (2004) Life history and propagation of the endangered dromedary pearlymussel (Dromus dromas) (Bivalvia:Unionidae). J N Am Benthol Soc 23:515-525

Jones JW, Mair RA, Neves RJ (2005) Factors affecting survival and growth of juvenile freshwater mussels cultured in recirculating aquaculture systems. N Am J Aquac 67:210-220

> Karna DW, Millemann RE (1978) Glochidiosis of salmonid fishes. III. Comparative susceptibility to natural infection with Margaritifera margaritifera (L.) (Pelecypoda: Margaritanidae) and associated histopathology. J Parasitol 64: 528-537

Lahnsteiner F, Jagsch A (2005) Changes in phenotype and genotype of Austrian Salmo trutta populations during the last century. Environ Biol Fishes 74:51-65

Layzer JB, Madison LM (1995) Microhabitat use by freshwater pearl mussels and recommendations for determining their instream flow needs. Regul Rivers Res Manag 10: 329-345

Machordom A, Araujo R, Erpenbeck D, Ramos MA (2003) Phylogeography and conservation genetics of endangered European Margaritiferidae (Bivalvia: Unionoidea). Biol J Linn Soc 78:235-252

> Mandal RN, Kumar K, Mohanty UL, Meher PK (2007) Estimation of gut contents of freshwater mussel, Lamellidens marginalis L. Aquac Res 38:1364-1369

Meffe G (1992) Techno-arrogance and halfway technologies: salmon hatcheries on the Pacific coast of North America. Conserv Biol 6:350-354

Meyers TR, Millemann RE (1977) Glochidiosis of salmonid fishes. I. Comparative susceptibility to experimental infection with Margaritifera margaritifera (L.) (Pelecypoda: Margaritanidae). J Parasitol 63:728-733

Morales JJ, Negro AI, Lizana M, Martinez A, Palacios J (2004) 
Preliminary study of the endangered populations of pearl mussel Margaritifera margaritifera (L.) in the River Tera (north-west Spain): habitat analysis and management considerations. Aquat Conserv Mar Freshw Ecosyst 14:587-596

Naimo TJ, Cope WG, Monroe EM, Farris JL, Milam CD (2000) Influence of diet on survival, growth, and physiological condition of fingernail clams Musculium transversum. J Shellfish Res 19:23-28

Neves RJ, Widlak JC (1987) Habitat ecology of juvenile freshwater mussels (Bivalvia:Unionidae) in a headwater stream in Virginia. Am Malacol Bull 5:1-7

Preston SJ, Keys A, Roberts D (2007) Culturing freshwater pearl mussel Margaritifera margaritifera: a breakthrough in the conservation of an endangered species. Aquat Conserv Mar Freshw Ecosyst 17:539-549

Reis J (2003) The freshwater pearl mussel [Margaritifera margaritifera (L.)] (Bivalvia, Unionoida) rediscovered in Portugal and threats to its survival. Biol Conserv 114:447-452

Ross HCG (1992) The reproductive biology of the freshwater pearl mussel Margaritifera margaritifera (L.) in Co. Donegal. Ir Nat J 24:43-50

Rudzite M (2004) Distribution of the freshwater pearl mussel Margaritifera margaritifera (Linnaeus 1758) in Latvia in relation to water quality. Acta Univ Latv Biol 676:79-85

Skinner A, Young MR, Hastie LC (2003) Ecology of the freshwater pearl mussel. Conserving Natura 2000 Rivers Ecology Series No. 2, English Nature, Peterborough

Smith DG (1979) Marsupial anatomy of the demibranch of Margaritifera margaritifera (L.) in northeastern North America (Pelecypoda: Unionacea). J Molluscan Stud 45: 39-44

Stone J, Barndt S, Gangloff M (2004) Spatial distribution and habitat use of the western pearlshell mussel (Margaritifera falcata) in a western Washington stream. J Freshw Ecol 19:341-352

Strayer DL (2008) Freshwater mussel ecology: a multifactor approach to distribution and abundance. University of California Press, London

Strayer DL, Downing JA, Haag WR, King TL, Layzer JB, Newton TJ, Nichols SJ (2004) Changing perspectives on pearly mussels, North America's most imperiled animals. Bioscience 54:429-439

Taylor J (2007) Captive breeding and juvenile culture of the freshwater pearl mussel (Margaritifera margaritifera): restoration of a critically endangered species. Finfish News 4:23-24

Treasurer JW, Hastie LC, Hunter D, Duncan F, Treasurer CM (2006) Effects of (Margaritifera margaritifera) glochidial infection on performance of tank-reared Atlantic salmon

Editorial responsibility: Paul Snelgrove,

St. Johns, Canada
(Salmo salar). Aquaculture 256:74-79

Valovirta I (1998) Conservation methods for populations of Margaritifera margaritifera (L.) in Finland. J Conchol Spec Publ 2:251-256

Wächtler K, Dreher-Mansur MC, Richter T (2000) Larval types and early postlarval biology in Naiads (Unionoida). In: Bauer G, Wächtler K (eds) Ecology and evolution of the freshwater mussels Unionoida. Springer, New York, NY, p 93-125

Walker AF (2007) Stream spawning of Arctic charr in Scotland. Ecol Freshw Fish 16:47-53

Watters GT, O'Dee SH (1999) Glochidia of the freshwater mussel Lampsilis overwintering on fish hosts. J Moll Stud 65:453-459

Williams JD, Warren ML Jr, Cummings KS, Harris JL, Neves RJ (1993) Conservation status of freshwater mussels of the United States and Canada. Fisheries 18:6-22

> Winkel EHT, Davids C (1982) Food selection by Dreissena polymorpha Pallas (Mollusca: Bivalvia). Freshw Biol 12: 553-558

- Young MR, Williams J (1983) The status and conservation of the freshwater pearl mussel in Great Britain. Biol Conserv 25:35-52

Young MR, Williams J (1984a) The reproductive biology of the freshwater pearl mussel in Scotland. I. Field studies. Arch Hydrobiol 99:405-422

Young MR, Williams J (1984b) The reproductive biology of the freshwater pearl mussel in Scotland. II. Laboratory studies. Arch Hydrobiol 100:29-42

Zanatta DT, Murphy RW (2007) Range-wide population genetic analysis of the endangered northern riffleshell mussel, Epioblasma torulosa rangiana (Bivalvia: Unionoida). Conserv Genet 8:1393-1404

Zimmerman LL, Neves RJ, Smith DG (2003) Control of predacious flatworms Macrostomum sp. in culturing juvenile freshwater mussels. N Am J Aquac 65:28-32

Ziuganov VV (2005) A long-lived parasite extending the host life span: the pearl mussel Margaritifera margaritifera elongates host life by turns out the program of accelerated senescence in salmon Salmo salar. Dokl Biol Sci 403: 291-294

Ziuganov VV, Zotin A, Nezlin L, Tretiakov V (1994) The freshwater pearl mussels and their relationships with salmonid fish. Russian Federal Research Institute of Fisheries and Oceanography, VNIRO, Moscow

Ziuganov VV, San Miguel E, Neves RJ, Longa A and others (2000) Life span variation of the freshwater pearl shell: a model species for testing longevity mechanisms in animals. Ambio 29:102-105

Submitted: February 16, 2009; Accepted: April 12, 2010

Proofs received from author(s): May 27, 2010 